\title{
TRANSAKSI LIKUIDITAS DI LEMBAGA KEUANGAN MIKRO SYARIAH DITINJAU DARI HUKUM EKONOMI ISLAM
}

\author{
Suhatri Mariko \\ Pegawai BPR Luhak Nan Tuo Kab. Tanah Datar \\ e-mail: suhatrimariko@gmail.com
}

\begin{abstract}
This qualitative research was aimed at describing the implementation Qardh and Wadiah Yad Dhamanah in the transaction of liquidity which was done by KJKS- BMT in Tanah Datar and the perpective of Islamic Economy Law toward the implementation of this transaction. The results revealed that the implementation of transaction liquidity (KJKS-BMT) in Tanah Datar Regency was conducted in two kinds of transactions Wadi'ah Yad Dhamanah and Qardh. According to Islamic Economy Law Wadi'ah Yad Dhamanah was accepted and Qardh was forbidden.
\end{abstract}

Keywords: Transaction of Liquidity, Micro Syari'ah Financial Institution, Economy Syari'ah

\section{PENDAHULUAN}

Lembaga KeuanganSyariah (LKS) adalah lembaga keuangan yang bekerja (beroperasi) menurut prinsip dan konsep syariah dengan prinsip profit and losssharing sebagai metode utama. Dalam struktur lembaga keuangan syariah dikelompokan menjadi bank umum syariah, BPR syariah dan Baitul Mal wat Tamwil. Ketiga lembaga ini mempunyai produk dan pangsa pasar yang berbeda. Namun dari segi prinsip dan instrumen yang digunakan ketiga lembaga keuangan syariah tersebut tidak mempunyai perbedaan yang cukup mendasar yaitu hanya pada ruang lingkup wilayah operasionalnya saja (Martono, 2002: 2).

Baitul Mal wat Tamwil atau disingkat dengan BMT terdiri dari dua istilah, yaitu baitul mal dan baitul tamwil. Baitul Mal lebih mengarah pada usaha-usaha pengumpulan dan penyaluran dana yang nonprofit, seperti zakat, sedekah dan infak. Sedangkan baitul tamwil merupakan suatu wadah yang lebih mengarah pada usaha-usaha pengumpulan dana dan penyaluran dana yang bersifat profit dengan memakai sistem profit and loss sharing, seperti pemberian pembiayaan murabahah, mudharabah dan lain sebagainya (Iska dan Rizal, 2005: 82).

Sebagai lembaga yang bergerak dalam jasa keuangan sebagaimana lembaga keuangan lain seperti bank, maka BMT tidak lepas dari risiko-risiko yang dihadapi dalam operasionalnya di lapangan dan yang menyebabkan bervariasinya 
tingkat keuntungan (profitabilitas) BMT. Salah satunya adalah risiko likuiditas, yakni risiko yang dialami karena BMT gagal melakukan pembayaran terhadap kewajibannya yang jatuh tempo. Resiko dapat bersumber dari aktivitas BMT dalam bidang pembiayaan, penyediaan dana, dan instrumen hutang. Menurut Wirdaningsih (2005: 140) likuiditas pada umumnya adalah mengenai posisi uang kas suatu perusahaan dan kemampuannya untuk memenuhi kewajiban (membayar utang) yang jatuh tempo tepat pada waktunya.

Berkaitan dengan permasalahan likuiditas yang dihadapi oleh lembaga keuangan mikro syariah seperti BMT, tentunya tidak bisa secara lansung menggunakan instrumen-instrumen likuiditas yang berlaku di perbankan syariah pada umumnya, sebab antara bank dan BMT memilki aturan yang berbeda, kendatipun secara operasional ada kesamaan. Di Indonesia, BMT termasuk dalam kelompok lembaga keuangan mikro syariah yang rata-rata berbadan Koperasi Jasa Keuangan Syariah (KJKS). Dalam menjalankan kegiatan operasional, BMT harus tunduk pada ketentuan dan aturan yang ada dalam undang-undang koperasi, termasuk juga ketentuan yang diatur dalam fatwa Dewan Syariah Nasional yang berkaitan dengan produk yang dipasarkan.
Dari tataran aplikatif, lembaga keuangan mikro syariah (KJKS-BMT) juga mengalami permasalahan likuiditas. Permasalahan likuiditas yang dialami oleh BMT dapat terjadi dalam dua kondisi. Pertama terjadinya kelebihan likuiditas, dalam mengatasi kelebihan likuiditas tersebut, BMT menginvestasikan dananya dalam bentuk tabungan dan atau simpanan berjangka pada Koperasi Jasa Keuangan Syariah lainnya atau dalam bentuk investasi-investasi lainya yang tidak bertentangan dengan prinsip syariah. Kedua terjadinya kekurangan likuiditas, dalam mengatasi kekurangan likuiditas, BMT melakukan transaksi likuiditas seperti mengajukan pinjaman dari BMT lain yang memilki kelebihan likuiditas berupa pinjaman jangka pendek maupun menerima penempatan dana antar BMT dalam bentuk simpanan.

Fenomena di atas juga terjadi di Lembaga Keuangan Mikro Syariah (KJKS- BMT) di Kabupaten Tanah Datar. Dari survey awal yang peneliti lakukan di beberapa KJKS-BMT yang beroperasi di Kabupaten Tanah Datar, diperoleh informasi, bahwa pengelola KJKS-BMT tersebut sering melakukan transaksi likuiditas antar BMT dalam bentuk pembiayaan atau pinjaman jangka pendek dengan menggunakan akad Qardh, 
dan juga penempatan atau titipan dana antar BMT dengan menggunakan akad Wadi'ah Yad Dhamanah. Menurut pengelola BMT di Kabuapetan Tanah Datar, tujuan dilakukannya transaksi likuiditas tersebut adalah untuk saling membantu antar sesama BMT yang mengalami kekurangan likuiditas.

Menguatkan pernyataan di atas, pada tanggal 13 Januari 2012 lima unit dari tujuh BMT yang ada di Kabupaten Tanah Datar membuat suatu perkumpulan bernama Forum Komunikasi Lembaga Keuangan Syariah (FKLKS). BMT yang ikut dalam FKLKS adalah KJKS BMT Darussalam, KJKS BMT Ampek Jurai, KJKS BMT El Amin, KJKS BMT Al Barokah dan KJKS BMT Al Hikmah. Penelitian ini bertujuan untuk mendeskripsikan bagaimana penerapan akad (Qardh dan Wadiah Yad Dhamanah) dalam transaksi likuiditas yang dilakukan antar Lembaga Keuangan Mikro Syariah (KJKS-BMT) di Kabupaten Tanah Datar. Kemudian akan dilakukan analisis lebih jauh berdasarkan perspektif Hukum Ekonomi Islam terhadap penerapan akad Qradh dan Wadiah Yad Dhamanah dalam transaksi likuiditas tersebut.

\section{METODE PENELITIAN}

Jenis penelitian ini adalah kualitatif studi kasus (Moleong, 2007) yaitu menggambarkan pelaksanaan transaksi likuiditas antar Lembaga Keuangan Mikro Syariah (KJKS- BMT) di Kabupaten Tanah Datar. Kemudian menganalisa pelaksanaan transaksi likuiditas tersebut berdasarkan perspektif Hukum Ekonomi Islam. Penelitian ini dilakukan di lima Koperasi Jasa Keuangan Syariah-BMT di Kabupaten Tanah Datar yang telah melaksanakan transaksi likuiditas antar BMT antara lain 1) KJKS BMT Darussalam Simabur; 2) KJKS BMT Ampek Jurai Batusangkar; 3) KJKS BMT El-Amin Batusangkar; 4) KJKS BMT Al- Barokah Sungai Tarab; 5) KJKS BMT AlHikmah Tabek Patah. Teknik pengumpulan data yang dilgunakan adalah wawancara dan studi dokumen yang berkaitan dengan permasalahan yang diteliti. Data yang diperoleh, kemudian dianalisis secara kualitatif dengan menggunakan model Miles dan Huberman (1994).

\section{HASIL PENELITIAN DAN PEMBAHASAN}

Pelaksanaan Transaksi Likuiditas pada Koperasi Jasa Keuangan Syariah (KJKS) BMT di Kabupaten Tanah Datar, diawali dari kesepakatan yang dibuat dalam Forum Komunikasi Lembaga Keuangan Syariah (FKLKS) Tanah Datar. Forum tersebut didirikan pada bulan Januari 2012 yang di ketuai oleh saudari Gusnova Aries, S.E.I. Forum Komunikasi Lembaga Keuangan 
Syariah (FKLKS merupakan wadah bagi BMT-BMT untuk menjalin kerja sama demi kemajuan BMT-BMT yang berada di Kabupaten Tanah Datar, setiap persoalan dan kendala yang dihadapi oleh masingmasing BMT akan dibantu penyelesaiannya oleh lembaga tersebut, termasuk dalam masalah likuiditas BMT.

\section{Transaksi Likuiditas Berupa Titipan Dana antar BMT}

Pelaksanaan transaksi Likuiditas dalam bentuk titipan dana antar BMT ini dilakukan dalam kondisi BMT mengalami kelebihan likuiditas dan juga dalam kondisi BMT mengalami kekurangan likuiditas. Dalam transaksi likuiditas ini pihak BMT menerapkan akad Wadiah Yad Dhamanah dengan proses sebagai berikut.

a. BMT yang mengalami kesulitan likuiditas mengajukan permohonan secara lisan kepada manajer BMT yang memilki kelebihan likuiditas.

b. Berdasarkan permohonan tersebut, BMT yang mengalami kelebihan likuiditas berkoordinasi dengan kasir dan bagian pembukuan untuk memastikan kondisi kas yang mereka miliki, kemudian atas kesepakatan internal di BMT tersebut, maka manajer BMT yang mengalami kelebihan likuiditas memberikan bantuan dana yang dibutuhkan kepada BMT pemohon.

c. Dana yang diberikan tersebut disetorkan ke rekening simpanan BMT yang mengalami kelebihan likuiditas yang ada di BMT pemohon (karena berdasarkan kesepakatan bersama, masing-masing BMT yang tergabung dalam kelompok FKLKS diharuskan memiliki rekening simpan dimasing-masing BMT).

d. BMT yang memberikan bantuan dana menerima bukti penyetoran simpanan di BMT pemohon, kemudian bagian pembukuan lansung melakukan pencatatan dengan cara mengurangi jumlah kas yang ada dan menambah jumlah simpanan BMT pemberi bantuan di BMT pemohon.

Jumlah transaksi likuiditas yang dilakukan antar BMT di Kabupaten Tanah maksimal berjumlah Rp. 5.000.000,- setiap kali transaksi. Aktifitas transaksi Likuiditas ini dilakukan maksimal satu kali dalam satu bulan. Di antara BMT yang sering memberikan bantuan likuiditas kepada BMT lain adalah BMT Darussalam dan BMT Ampek Jurai, sementara 
BMT Al-Hikmah Tabek Patah, BMT Al-Baroqah Sungai Tarab dan BMT El Amin Batusangkar adalah BMT yang sering mengalami kesulitan likuiditas. Dari transaksi likuiditas dalam bentuk penempatan dana ini, pihak BMT yang menitipkan dana tidak menerima bagi hasil ataupun insentif dari BMT yang memanfaatkan dana transaksi ini sifatnya tolong menolong dan sekaligus melaksanakan komitmen bersama dalam FKLKS. Kemudian jangka waktu penitipan dana tersebut biasanya maksimal satu bulan, di saat BMT yang menitipkan dana membutuhkan dana, BMT yang menerima titipan harus siap megembalikan dana tersebut kepada BMT Darussalam.

\section{Transaksi Likuiditas berupa} Pembiayaan dengan Menggunakan akad Qardh

Di samping bentuk transaksi likuiditas berupa titipan dana antar BMT. Pelaku BMT di Kabupaten Tanah Datar juga pernah melakukan transaksi likuiditas berupa pemberian pembiayaan atau pinjaman kepada BMT Lain yang membutuhkan dana dengan menggunakan akad Al-Qardh. Transaksi likuiditas ini dilakukan dengan proses sebagai berikut. a. BMT yang membutuhkan bantuan likuiditas mengajukan permohonan secara tertulis kepada BMT lain yang memiliki kelebihan dana, permohonan tersebut dibuat atas nama pengurus atau manajer BMT pemohon. Dalam surat permohonan tersebut tertulis jumlah pinjaman, jangka waktu pinjaman dan tujuan pinjaman (misalnya jumlah pinjaman Rp.10.000.000,- jangka waktu 1 bulan dengan tujuan untuk membantu kesulitan likuiditas).

b. Berdasarkan permohonan tersebut, pihak BMT yang akan memberikan bantuan berkoordinasi dengan seluruh pengelola dan pengurus mereka, kemudian atas kesepakatan internal di BMT tersebut, merealisasikan pembiayaan kepada BMT pemohon.

c. Setelah seluruh kelengkapan pembiayaan selesai dibuat, maka pembiayaan lansung direalisasikan dan ditandatangani oleh manajer dan salah satu anggota pengurus BMT pemohon.

d. Dalam akad pembiayaan Al-qardh yang disediakan oleh BMT yang memberikan bantuan dimuat beberapa ketentuan tentang pembiayaan Al-qardh tersebut, 
antara lain 1) jumlah pembiayaan Rp.10.000.000,-; 2) BMT Penerima fasilitas pinjaman diwajibkan membayar fee $1 \%$ per bulan dari jumlah pinjaman ditambah biaya pembelian materai dan map. 3) jangka waktu pinjaman satu bulan, apabila BMT yang mendapat fasilitas pinjaman Qardh tidak mampu membayar pinjaman tersebut pada waktu yang sudah disepakati, maka akad qardh tersebut diperbaharui kembali dan BMT yang mendapat fasilitas pinjaman diwajibkan kembali membayar fee $1 \%$ dari jumlah pinjaman.

BMT yang sudah pernah melakukan transaksi likuiditas jenis ini adalah BMT Ampek Jurai Batusangkar. Dari keterangan yang diperoleh dari pihak BMT Ampek Jurai diungkapkan bahwa transaksi likuiditas jenis ini jarang sekali dilakukan. Selama tahun 2014 BMT Ampek Jurai baru merealisasikan pembiayaan al- qardh ini sebanyak dua kali transaksi dengan nominal pembiayaan sebesar Rp. 20.000.000,- . Atas pembiayaan Al-Qardh ini BMT Ampek Jurai tidak meminta barang atau sesuatu yang berharga sebagai jaminan kepada BMT penerima fasilitas

96 Jurnal Tamwil, Vol. I, No. 2, Juli-Desember 2015 pembiayaan. Yang menjadijaminan atas transaksi ini hanyalah saling percaya di antara kedua belak pihak. Lebih lanjut, manajer BMT Ampek jurai menyatakan, bahwa sebenarnya pengambilan fee $1 \%$ dari pembaiayaan qardh tersebut adalah pengganti biaya administrasi, $\mathrm{di}$ samping pihak BMT juga menagambil biaya penggantian pembelian materai dan map untuk keperluan akad qardh.

2. Pandangan Hukum Ekonomi Islam Terhadap Pelaksanaan Transaksi Likuiditas yang dilakukan oleh BMT di Kabuapaten Tanah Datar

\section{a. Pelaksanaan Transaksi likuiditas berupa Penempatan Dana antar BMT}

Akad wadi'ah termasuk kategori akad tabarru', yaitu segala macam perjanjian yang menyangkut notprofit transaction (transaksi nirlaba). Transaksi ini pada hakikatnya bukan transaksi bisnis untuk mencari keuntungan komersil, tetapi bertujuan tolong-menolong dalam rangka berbuat kebaikan. Dalam akad tabarru', pihak yang berbuat kebaikan tersebut tidak berhak mensyaratkan imbalan apapun kepada pihak lainnya. Imbalan akad tabarru' adalah dari Allah SWT. Namun pihak yang 
berbuat kebaikan boleh meminta counter partnya untuk sekedar menutup biaya (cover the cost) yang dikeluarkanya untuk melakukan akad tabarru' tersebut, tetapi tidak boleh mengambil laba sedikitpun (Karim, 2006: 68).

Aplikasi di perbankan syari'ah akad al-wadi'ah digolongkan menjadi dua bagian, yakni Wadiah Yad Al-Amanah dan wadi'ahyaddamanah (Ridwan, 2004: 107). Dalam Wadiah Yad Al-Amanah pihak yang menerima titipan tidak boleh memanfaatkan barang atau benda sehingga orang/bank yang dititipi hanya berfungsi sebagai penjaga barang tanpa memanfaatkannya. Barang atau aset yang dititipkan adalah sesuatu yang berharga yang berupa uang, barang, dokumen, surat berharga, sertifikat tanah, sertifikat deposito, saham, ijazah, BPKB, perhiasan, berlian, emas dan lain sebagainya. Sebagai konsekuensinya yang menerima titipan dapat saja mensyaratkan adanya biaya penitipan. Praktik semacam ini dalam perbankan berlaku akad safe deposit box atau kotak penitipan (Ascarya, 2007: 23, 107-108)
Dengan prinsip ini, pihak penyimpanan tidak boleh menggunakan atau memanfaatkan barang atau aset yang dititipkan, melainkan hanya menjaganya. Selain itu, barang atau aset yang dititipkan tidak boleh dicampur adukkan dengan barang atau aset lain, melainkan harus dipisahkan untuk masing-masing barang atau aset penitip.

Akad wadi'ah yang kedua yaitu Wadi'ah yad-dhamanah yaitu penitipan barang/uang di mana pihak penerima titipan dengan atau tanpa izin pemilik barang/uang dapat memanfaatkan barang/uang titipan dan harus bertanggung jawab terhadap kehilangan atau kerusakan barang/uang titipan (Wirdyaningsih : 2005,125$)$ Jenis akad wadi'ah ini yang dipraktekan oleh Koperasi Jasa Keuangan Syariah (KJKS) BMT di Kabupaten Tanah Datar.

Dalam pelaksanaan akad wadi'ah yad dhamanah, BMT yang menerima titipan dapat memanfaatkan dana al-wadi'ah untuk mengatasi kesulitan likuiditas yang dihadapi (seperti penarikan simpanan secara mendadak oleh 
nasabah dan membayar kewajiban lainya yang sifatnya mendesak atau merealisasikan pembiayaan terhadap nasabah yang sudah dijanjikan sebelumnya). Segala hasil dan resiko yang diperoleh dari pengelolaan dana tersebut menjadi milik penerima titipan (termasuk penanggung semua kemungkinan kerugian). Sebagai imbalannya pihak BMT yang menitipkan dana mendapat jaminan keamanan terhadap harta atau uangnya tersebut termasuk menerima kembali titipan tersebut secara utuh pada saat di butuhkan. Dalam pelaksanaan akad wadi'ah yad dhamanah ini pihak BMT yang menitipkan dana tidak mendapatkan imbalan atas pemanfaatan dana tersebut.

Dari penjelasan di atas dapat disimpulkan, bahwa pelaksanaan transaksi likuiditas oleh Koperasi Jasa Keuangan syariah (KJKS) BMT di Kabupaten Tanah Datar dalam bentuk penitipan dana antar BMT dengan menerapkan prinsip tabungan wadi'ah yad adh-dhamanah sejalan dengan pendapat ulama, pakar Hukum Ekonomi Islam serta Fatwa 02/DSN-MUI/IV/2000 tentang tabungan yang menerapkan prinsip wadi'ah. Di mana kedua pihak yang bertransaksi tidak mensyaratkan untuk menerima atau memberi imbalan berupa bonus atau sejenisnya dari pemanfaatan dana wadi'ah tersebut, karena tujuan dari transaksi likuiditas yang dilakukan adalah murni untuk membantu kesulitan likuiditas antar sesama BMT.

\section{b. Pelaksanaan Transaksi Likuiditas} berupa Pembiayaan Qardh

Pelaksanaan transaksi likuiditas yang dilakukan oleh Koperasi Jasa Keuangan Syariah (KJKS) BMT di Kabupaten Tanah Datar dengan menggunakan akad qardh tidak sesuai dengan Hukum Ekonomi Islam, karena mengambil keuntungan berupa fee sebesar $1 \%$ (satu persen) dari pinjaman qardh sama dengan bunga pinjaman di Bank Konvensional yang tergolong pada riba yang diharamkan Allah SWT. Walaupun sejak tahun 2015 akad qardh yang lama telah diubah di mana pengambilan fee $1 \%$ menjadi biaya administrasi dari jumlah pembiayaan, maka perubahan tersebut juga tidak sesuai dengan isi Fatwa 19/DSN- 
MUI/IX/2000 yang menyatakan pengambilan biaya administrasi pembiayaan qardh tidak boleh dalam bentuk persentase.

Pelaksanaan akad qardh yang dilakukan oleh Koperasi Jasa Keuangan Syariah (KJKS) BMT di Kabupaten Tanah Datar selama tahun 2014 dengan mengambil keuntungan atas pembiayaan berupa fee sebesar $1 \%$ (satu persen) dari jumlah pembiayaan yang diberikan dan keuntungan yang diambil tersebut juga disyaratkan dan dituliskan dalam akad pembiayaan. Praktek tersebut telah menyalahi prinsip dasar dari qardh. Sebagainaman yang diungkapkan Zulkifli (2003:13) di mana prinsip dasar dari qardh merupakan pinjaman kebajikan dengan unsur tolong-menolong (tabarru').

Secara fiqih, orang yang meminjami uang (muqridh) tidak boleh meminta manfaat apa pun dari yang dipinjaminya (muqtaridh). Hal ini sesuai dengan sabda Rasulullah Saw sebagaimana yang diriwayatkan dari al- Harith bin Abi Usamah dari Ali r.a: (Sunan al- Kubra li al- Baihaqi.

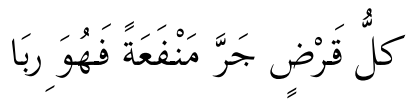

"Setiap akad qardh dilaksanakan dengan mengambil keuntungan maka ia tergolong kepada riba."

Jenis transaksi likuiditas yang dijalankan oleh Koperasi Jasa Keuangan Syariah (KJKS) BMT di Kabupaten Tanah Datar berupa pinjaman qardh yang bertentangan dengan Hukum Ekonomi Islam, karena praktiknya hampir sama dengan bunga pinjaman di Bank Konvensional. Menurut hemat penulis akad qardh yang diterapkan untuk transaksi likuiditas yang dilakukan, dicarikan alternatif akad baru, yaitu akad tijarah. Akad tijarah/muawadah adalah segala macam perjanjian yang menyangkut for profit transaction. Akad-akad ini dilakukan dengan tujuan mencari keuntungan, karena bersifat komersil, contohnya Rahn, sewamenyewa (ijarah), investasi dll (Karim: 2006, 72)

Adapun alasan dan pertimbangan penulis mencoba menawarkan alternatif akad baru sebagai pengganti dari akad qardh yang diterapkan untuk transaksi likuiditas oleh BMT adalah mengingat sumber dana yang digunakan BMT untuk memberikan pinjaman qardh berasal dari kelebihan kas yang dimilki, di mana kas yang ada di BMT tersebut bersumber dari modal, cadangan dan dana pihak ketiga (tabungan dan Deposito), serta sumber kas lainya. Dari sumber dana ini, tentunya 
pihak BMT punya biaya yang harus dikeluarkan terhadap dana tersebut seperti biaya operasional dan gaji karyawan yang menghimpun dan mengelola dana tersebut dan deviden kepada pemegang saham serta bagi hasil/ bonus kepada anggota maupun nasabah.

Apabila sumber dana tersebut yang dipakai oleh BMT untuk membantu kesulitan likuiditas BMT lain dengan menggunakan akad qardh tentunya pihak BMT yang memberikan pinjaman tidak akan mendapat keuntungan, sementara biaya atas dana tersebut harus dibayarkan. Maka agar pelaku Lembaga Keuangan Mikro Syariah (KJKS-BMT) di Kab. Tanah Datar dapat melaksanakan fungsinya sebagai suatu lembaga yang juga beroreantasi profit atau disebut sebagai Baitul Tamwil (rumah pengembangan harta), yang melakukan kegiatan pengembangan usaha-usaha produktif dan investasi dalam meningkatkan kualitas ekonomi pengusaha mikro dan kecil dengan antara lain mendorong kegiatan menabung dan menunjang pembiayaan kegiatan ekonomi (Huda dan Edwin, 2007). Dari penjelasan di atas dapat ditarik suatu kesimpulan bahwa untuk menghindari praktik riba dari pelaksanaan akad qardh yang dilakukan Lembaga Keuangan Mikro Syariah (KJKS-BMT) di Kab. Tanah Datar untuk membantu kesulitan likuiditas BMT lain, maka akad yang bisa diterapkan untuk transaksi likuiditas antar BMT adalah akad tijarah berupa investasi dengan menerapkan akad mudharabah muqayadah.

\section{KESIMPULAN}

1. Pelaksanaan transaksi likuiditas yang dilakukan Lembaga Keuangan Mikro Syariah (KJKS - BMT) di Kabupaten Tanah Datar, dilakukan dalam dua jenis transaksi wadi'ah yad adh-dhamanah dan qardh.

2. Dari dua jenis transaksi likuiditas yang dilakukan oleh Lembaga Keuangan Mikro Syariah (KJKS BMT) di Kabupaten Tanah Datar, maka transaksi likuiditas dalam bentuk titipan dana sudah sesuai dengan Hukum Ekonomi Islam, karena telah menerapkan prinsip akad wadi'ah yad adh-dhamanah. Sementara transaksi likuiditas berupa pembiayaan qardh tidak sesuai dengan Hukum Ekonomi Islam, karena mengambil keuntungan atau manfaat dari pinjaman yang diberikan berupa fee sebesar 1\% (satu persen) dan tahun 2015 dalam akad qardh fee $1 \%$ dirobah menjadi biaya administasi sebesar 1\%. Perobahan ini juga bertentangan dengan isi Fatwa Dewan Syariah Nasional Nomor : 
19/DSN-MUI/IV/2001 tentang alQardh yang tidak boleh mengambil biaya administrasi dalam bentuk persentase, karena substansinya sama dengan praktek bunga pinjaman atau kredit pada Bank Konvensional yang tergolong riba yang diharamkan dalam Alqur'an dan Sunnah beserta Ijma' Ulama. Kemudian pengambilan biaya administrasi berupa pengantian pembelian materai dan map dan kebutuahn lain dalam pembuatan akad qrdh sudah sesuai dengan Fatwa Dewan Syariah Nasional Nomor : 19/ DSN-MUI/IV/2001 tentang al-Qardh.

\section{KEPUSTAKAAN ACUAN}

Ascarya. (2007). Akad E Produk Bank Syariah. Jakarta: PT Rajagrafindo Persada.

Fatwa Dewan Syariah Nasional Nomor 02/DSN-MUI/IV/2000 tentang Tabungan

Fatwa Dewan Syariah Nasional Nomor. 19/ DSN-MUI/IX/2000 tentang qardh.

Huda, Nurul. dan Edwin, Mustafa. (2007). Investasi Pasar Modal Syariah. Jakarta: Kencana Prenada Media Grup.
Iska, Syukri dan Rizal. (2005). Lembaga Keuangan Syariah. Batusangkar: STAIN Batusangkar Press.

Karim, Adiwarman. (2006) Bank Islam, Analisis Fiqih Dan Keuangan. Jakarta: PT Raja Grafindo Persada.

Martono. (2002). Bank dan Lembaga Keuangan Lain. Yogyakarta: Ekonisia.

Miles, Mathew B \& Huberman, A. Michael. (1994). Qualitative Data Analysis. An Expanded Sourcebook Second Edition. Thousand Oaks, CA: Sage.

Moleong, Lexy, J, (2007). Metodologi Penelitian Kualitatif. Bandung: PT. Remaja Rosdakarya

Ridwan, Muhammad. (2004). Manajemen Baitul Maal wa Tamwil (BMT), Yogyakarta: UII Press.

Wirdyaningsih dkk. (2005). Bank dan Asuransi Islam di Indonesia. Jakarta: Kencana.

Zulkifli, Sunarto. (2003). Panduan Praktis Transaksi Perbankan Syariah. Jakarta: Zikrul Hakim 